\title{
Nucleases isolated from Chelidonium majus L. milky sap can induce apoptosis in human cervical carcinoma HeLa cells but not in Chinese Hamster Ovary CHO cells
}

\author{
Robert Nawrot ${ }^{1}$, Maria Wołuń-Cholewa ${ }^{2}$, Anna Goździcka-Józefiak ${ }^{1}$ \\ ${ }^{1}$ Department of Molecular Virology, Institute of Experimental Biology, Faculty of Biology, \\ Adam Mickiewicz University, Poznań, Poland \\ ${ }^{2}$ Department of Cell Biology, University of Medical Sciences, Poznań, Poland
}

\begin{abstract}
Milky sap isolated from Chelidonium majus L. (Greater Celandine) serves as a rich source of various biologically active substances such as alkaloids, flavonoids and phenolic acids. Previous research showed that the activity of $C h$. majus milky sap may depend also on the presence of biologically active proteins. The goal of this study was to evaluate the biological effect of two nucleases isolated from Ch. majus milky sap, CMN1 of $20 \mathrm{kDa}$ and CMN2 of $36 \mathrm{kDa}$, on HeLa and $\mathrm{CHO}$ tumour cell lines. Both studied nucleases together with other proteins in the sap of the plant are involved in stress and defence reactions against different pathogens. After $48 \mathrm{~h}$ incubation of CMN1 and CMN2 only with HeLa cells, the dependence between the number of apoptotic lesions and the concentration of applied nuclease was observed. The highest proapoptotic activity was induced by $13.3 \mathrm{ng} / \mathrm{ml}$ concentration of CMN2 collected in May (62 $\pm 3 \%$ HeLa cells were apoptotic). Moreover, the proportion of necrotic cells in all concentrations of the nucleases and both cell lines was relatively low (1-8 $\pm 0.5 \%$ ). In summary, results of this study show that purified nucleases CMN1 and CMN2 isolated from Ch. majus milky sap exhibit apoptotic activity in HeLa tumour cell line, but not in CHO cells, without inflammatory reaction.
\end{abstract}

Keywords: Nuclease - Chelidonium majus - Apoptosis - HeLa cell line - CHO cell line

\section{Introduction}

Chelidonium majus L. (Greater Celandine) belongs to the Papaveraceae family and is widely distributed in Europe and Western Asia. Milky sap isolated from $C h$. majus serves as a rich source of various biologically active substances such as alkaloids, flavonoids and phenolic acids which have antitumour, antimicrobial, antifungal and fungistatic properties. Our previous research showed that the activity of Ch. majus milky sap may depend also on the presence of biologically active proteins which exhibit lectin CML and DN-ase activity $[1,13]$.

Recently, we have shown that crude protein extracts from Ch. majus milky sap collected from May to October show the presence of two nucleases of 20 and $36 \mathrm{kDa}$, named CMN1 and CMN2, respectively [2]. Proteomic analysis of Ch. majus milky sap

Correspondence: M. Wołun-Cholewa, University of Medical Sciences, Dept. of Cell Biology, Rokietnicka Str. 5D, 60-806 Poznań, Poland; tel.: (+4861) 8547186, fax.: (+4861) 8547169, e-mail: doskon@amp.edu.pl revealed that it contains a mixture of 21 proteins, among them CMN1 (pI around 5.3) and CMN2 (pI around 6.0), which are involved in stress and defence responses against different pathogens [3]. CMN1 nuclease was active in extracts collected in May, and CMN2 during the whole vegetation period (from May until October). Both proteins exhibit the highest activity in $\mathrm{Ca}^{2+}$ buffer, $\mathrm{pH}=8.0$, so they belong to the $\mathrm{Ca}^{2+}$ dependent nucleases class [4]. The activity of both nucleases is very high and changes during growth and development of the plant. Probably they participate in the cellular interaction required for the development and differentiation of plants and also may be involved in plant defence against pathogens. One of the studied nucleases (CMN1) may belong to pathogenesis-related protein family 10 (PR-10) [5].

A properly conducted therapy, for example cancer treatment, initially requires an appropriate concentration of a drug and appropriate duration of its action. In our study we used two nucleases isolated from $\mathrm{Ch}$. majus milky sap. These compounds are defined as the group of enzymes that are capable of hydrolyzing the phosphodiester linkages of nucleic acids. Ribonucleas- 


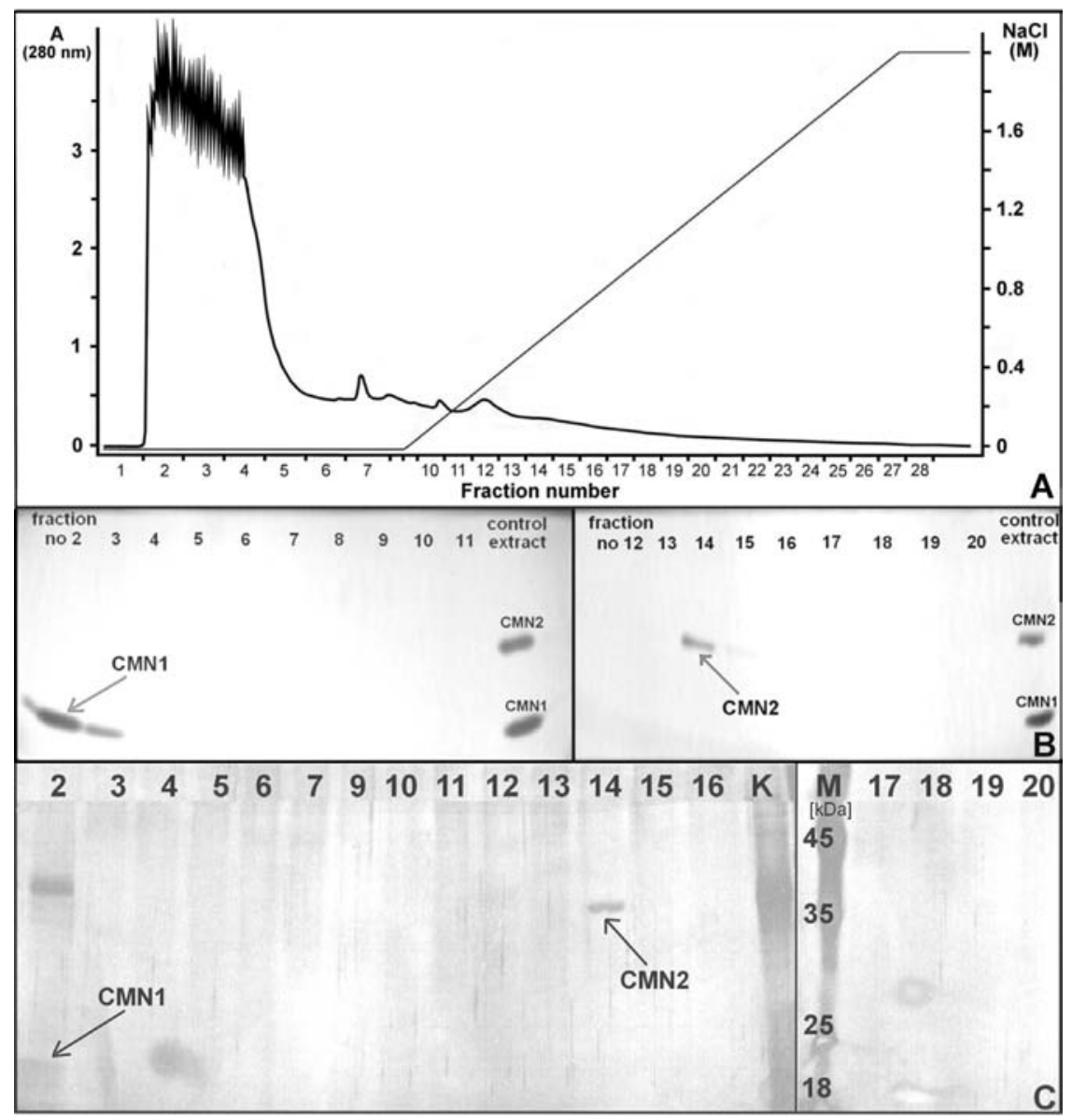

Fig. 1. (A) Fractionation of the extract of Ch. majus milky sap on HT Heparin column (GE Healthcare). Milky sap was collected in May. Numbers 1 to 8 represent the flowthrough fractions, fractions from 9 to 27 were eluted with the linear gradient of $\mathrm{NaCl}$ from 0 to $2 \mathrm{M}$. All fractions were monitored for absorbance at $280 \mathrm{~nm}$ and DN-ase activity. (B) In-gel DN-ase activity assay (ssDNA, $\mathrm{Ca}^{2+}, \mathrm{pH}=8.0$ ) shows that $\mathrm{CMN} 2$ is present in fraction no. 14, thus it binds to heparin and can be eluted with about $0.5 \mathrm{M}$ $\mathrm{NaCl}$. On the other hand, CMN1 does not bind to the column and is eluted with flowthrough fractions. (C) SDS-PAGE protein profile of silver-stained [8] fractions after purification of nucleases from Ch. majus milky sap on HT Heparin column (GE Healthcare); $\mathrm{M}$ - protein molecular weight marker (Fermentas). es (RN-ases) and deoxyribonucleases (DN-ases) are not only involved in nucleic acid metabolism, but also play important roles in many cellular processes. Moreover, nucleases are involved in host defence against foreign nucleic acid molecules [14]. Both studied nucleases display $\mathrm{DN}$-ase and $\mathrm{RN}$-ase activities (data not shown) and probably are a part of Chelidonium majus defence system. Together with other proteins in the sap of the plant, they are involved in stress and defence reactions against different pathogens.

The goal of this study was to evaluate the biological effect of CMN1 and CMN2 on HeLa and CHO tumour cell lines. Previously, the effect of lectin CML from Ch. majus on normal and cancer cells in culture was evaluated. Exposure to CML resulted in growth inhibition of $\mathrm{CHO}$ and $\mathrm{R} 2 \mathrm{C}$ cells but not of normal mouse fibroblasts [13]. To our knowledge, the present study demonstrates for the first time the action of nucleases isolated from Ch. majus milky sap on HeLa and $\mathrm{CHO}$ cells. HeLa cells originate from human cervical cancer, which was transformed with oncogenic human papillomavirus type 18 (HPV18). In contrast, CHO (Chinese Hamster Ovary) cells are an established line of fibroblasts from Chinese hamster ovary, which is frequently used in toxicity screening and genetic studies. Screening for the biological effects of newly described plant proteins on cell cultures could provide new insights into the search for proapoptotic and potentially therapeutic agents in cancer treatment.

\section{Materials and methods}

Plant material. Chelidonium majus plants were collected in the neighbourhood of Poznan from the early summer until autumn. The milky sap was isolated from stalks of the plants and dissolved in $0.1 \mathrm{M}$ Tris- $\mathrm{HCl}$ buffer, $\mathrm{pH}=8.0$, containing $10 \%$ glycerol (sap: buffer ratio was $1: 2)$. The milky sap $(33 \% \mathrm{v} / \mathrm{v})$ samples were separated into a supernatant, and a pellet fraction by centrifugation at $12000 \mathrm{rpm}$ for $20 \mathrm{~min}$ at $4^{\circ} \mathrm{C}$ as described [3] with modifications. Supernatants were stored at $-20^{\circ} \mathrm{C}$ for further analysis. Protein concentration in the milky sap was determined according to Lowry et al. [6].

Isolation and purification of nucleases. For isolation and purification of nucleases supernatants of crude milky sap extracts collected in May and October were used. About $0.5 \mu \mathrm{g}$ protein was loaded on HT Heparin column (GE Healthcare) $(0.7 \times 2.5 \mathrm{~cm})$ equilibrated with $0.1 \mathrm{M}$ Tris- $\mathrm{HCl}, \mathrm{pH}=8.0,10 \%$ glycerol. The column was eluted with a linear gradient of 0 to $2 \mathrm{M} \mathrm{NaCl}$ in the same buffer. Fractions of about $1 \mathrm{ml}$ were collected and the absorbance at $280 \mathrm{~nm}$ and DN-ase activity of all fractions were determined.

Analysis by SDS-PAGE. In order to verify the protein composition of chromatographic fractions, sodium dodecyl sulfate polyacrylamide gel electrophoresis (SDS-PAGE) was carried out in a slab mini-gel apparatus according to Laemmli [7], using $10 \%$ poly- 

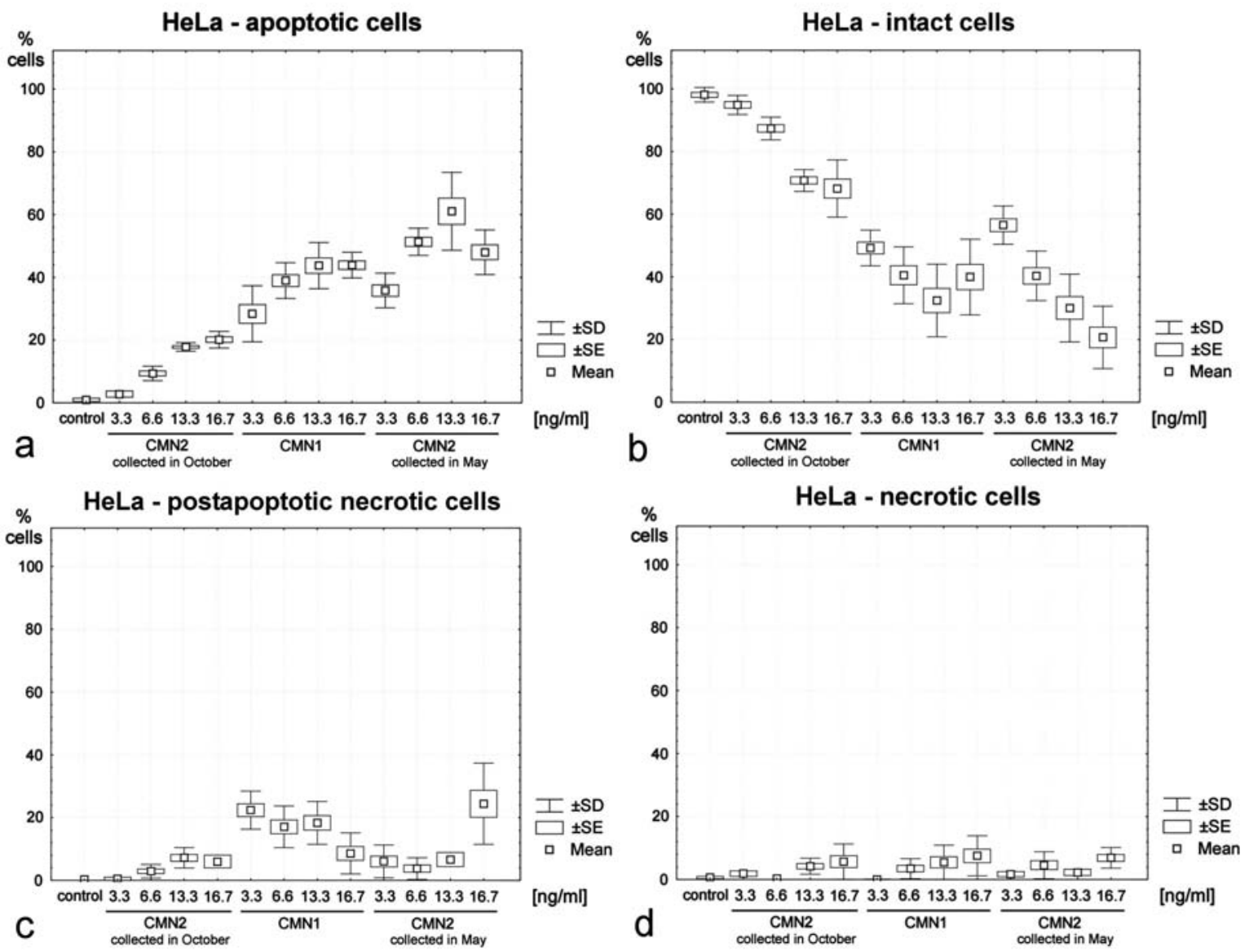

Fig. 2. Effect of CMN1 and CMN2 nucleases on HeLa cells after $48 \mathrm{~h}$ incubation with both of them in different concentrations. Control - $26.7 \mu \mathrm{l} / \mathrm{ml}$ elution buffer (0.1 M Tris- $\mathrm{HCl}, \mathrm{pH}=8.0,10 \%$ glycerol); SD - standard deviation; SE - standard error.

acrylamide as the separating gel and 5\% polyacrylamide as the stacking gel. The proteins were reduced by heating them to $100^{\circ} \mathrm{C}$ in the presence of 2-mercaptoethanol for $5 \mathrm{~min}$. Gels after SDSPAGE were fixed and stained with silver according to Shevchenko et al. [7] or Heukeshoven \& Dernick [8].

In-gel nuclease assay. An in-gel $\mathrm{DN}$-ase assay was performed according to Thelen \& Northcote [9], with modifications [10]. For in-gel DN-ase assay, Ch. majus extracts or fractions after purification were dissolved in SDS-PAGE sample buffer without a reducing agent, incubated at $37^{\circ} \mathrm{C}$ for $10 \mathrm{~min}$, and subjected to SDSPAGE on $10 \%$ polyacrylamide gel containing denatured calf thymus DNA $(40 \mu \mathrm{g} / \mathrm{ml})$. After electrophoresis and removal of SDS, gels were washed with reaction buffer $(10 \mathrm{mM}$ Tris- $\mathrm{HCl}, \mathrm{pH}=8.0$, containing $10 \mathrm{mM} \mathrm{CaCl}$ ). DN-ase activity was visualized by staining the gel with ethidium bromide. $\mathrm{RN}$-ase activity was assessed as described by Yen and Green [11], with some modifications [12].

Cell cultures. CHO cells were cultured in RPMI 1640 supplemented with $5 \%$ FCS, 2 mmol/1 L-glutamine, $100 \mu \mathrm{g} / \mathrm{ml}$ streptomycin and $100 \mathrm{U} / \mathrm{ml}$ penicillin. HeLa cells were maintained in the same conditions. $\mathrm{CHO}$ and HeLa cells were incubated for 24 and $48 \mathrm{~h}$ with purified fractions of CMN1 and CMN2 in concentrations of 3.3, 6.6, 13.3 and $16.7 \mathrm{ng} / \mathrm{ml}$. Cell cultures to which the elution buffer $(0.1 \mathrm{M}$ Tris- $\mathrm{HCl}, \mathrm{pH}=8.0,10 \%$ glycerol $)$ was added at 26.7 $\mu \mathrm{l} / \mathrm{ml}$ served as controls. After 24 and $48 \mathrm{~h}$ in each culture proportions of intact cells, apoptotic cells, postapoptotic necrotic (of nuclear structure typical of late apoptosis and cell membrane disruption characteristic for necrosis) and necrotic cells were evaluated using fluorescence staining with Hoechst $33342(0.1 \mu \mathrm{g} / \mathrm{ml})$ and propidium iodide $(0.125 \mu \mathrm{g} / \mathrm{ml})$ (Diaphot Eclipse TE 200 with UV$2 \mathrm{~A}$ and FITC/FLUO-3 filters, Nikon) [13]. Each experiment included 10 independent cultures and at least 500 cells were scored in each culture.

Staticstical analysis. Statistical analysis of the obtained results involved the test of difference between two structural parameters using STATISTICA software (ver. 6.1).

\section{Results \\ Purification of nucleases}

Nucleases CMN1 and CMN2 were isolated and purified using affinity chromatography on heparin column from extract of Ch. majus milky sap collected in May and October. All fractions were monitored for absorbance at $280 \mathrm{~nm}$ and DN-ase activity (Fig. 1A). Results of in-gel DN-ase activity assay (ssDNA, $\mathrm{Ca}^{2+}$, $\mathrm{pH}=8.0$ ) showed that CMN2 nuclease bound to heparin and could be eluted with about $0.5 \mathrm{M} \mathrm{NaCl}$. On the other hand, CMN1 nuclease did not bind to heparin and was eluted with flow-through fractions 

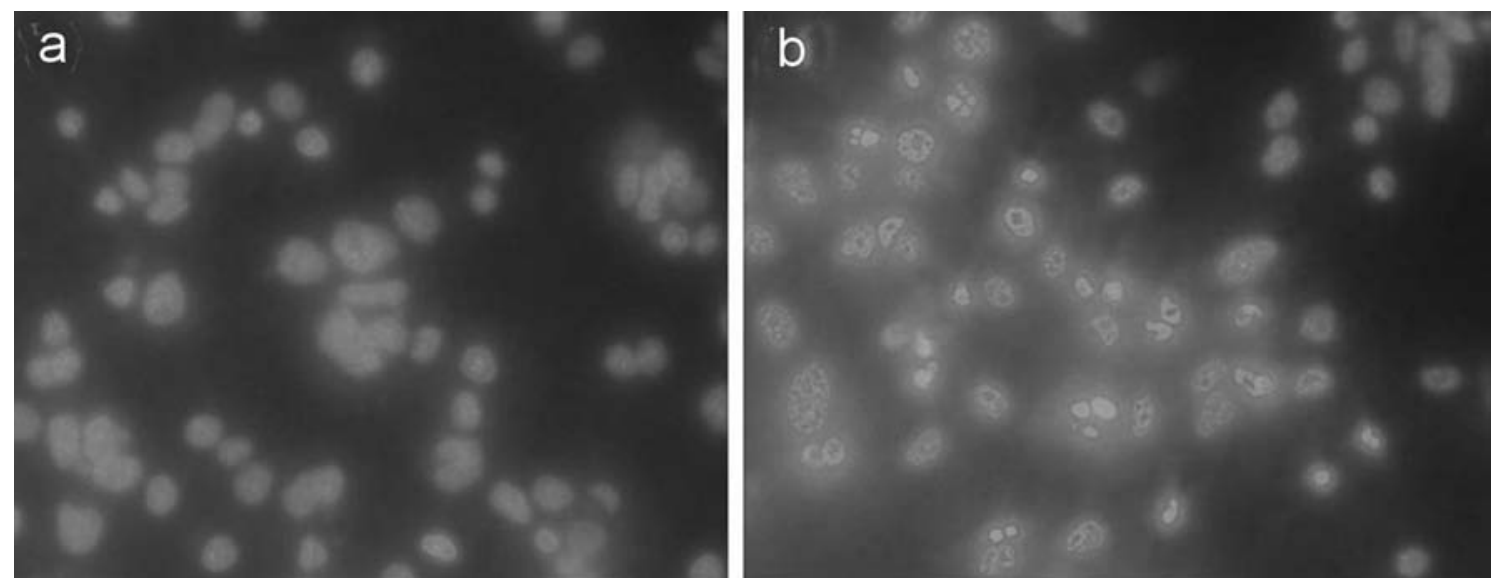

Fig. 3. (a) HeLa cells from the control group (magnification $\times 400)($ b) Apoptosis of HeLa cells after applying CMN1 nuclease in the concentration of $13.3 \mathrm{ng} / \mathrm{ml}$ after $48 \mathrm{~h}$ incubation (magnification $\times 400$ ).

but, nevertheless, it was partially purified (Fig. 1B and 1C). Unlike CMN2, CMN1 nuclease probably possessed a different physico-chemical characteristics.

\section{Cell lines}

The experiments showed that the effect of nucleases on HeLa and CHO cells depended on both the concentration and the time which elapsed after adding the protein to the incubation medium. It was shown that 24 $\mathrm{h}$ incubation of CMN1 and CMN2 with HeLa and $\mathrm{CHO}$ cell lines did not show any significant effects. No effects were also noted in CHO cell line after $48 \mathrm{~h}$ incubation with both nucleases in the applied concentration (data not shown). In contrast, after $48 \mathrm{~h}$ incubation of CMN1 and CMN2 with HeLa cells, a relationship was observed between the number of apoptotic lesions and the concentration of applied nuclease (Fig. 2). Partially purified CMN1 induced the highest apoptosis rate in concentrations of 13.3 and $16.7 \mathrm{ng} / \mathrm{ml}$ (about $44 \pm 2 \%$ of HeLa cells were apoptotic) (Fig. 2a and 3). The highest proapoptotic activity was induced by $13.3 \mathrm{ng} / \mathrm{ml}$ concentration of CMN2 collected in May (62 $\pm 3 \%$ HeLa cells were apoptotic) (Fig. 2a). Moreover, the proportion of necrotic cells in all concentrations of the nucleases and in both cell lines was relatively stable and low (1-8 $\pm 0.5 \%)$ (Fig. 2 d).

Additionally, image cytometric techniques allowed evaluation of the postapoptotic cell morphology. After $48 \mathrm{~h}$ of incubation with various concentrations of nucleases, apoptotic cells were accompanied by cells in so-called postapoptotic necrosis. These cells demonstrated a nuclear structure typical of late apoptosis and cell membrane disruption characteristic for necrosis. They could be distinguished from typical apoptotic cells, because they were stained with propidium iodide, which does not occur during apoptosis. The highest postapoptotic necrosis rate (about $20 \%$ of the cells) was observed following incubation with 3.3,
6.6 or $13.3 \mathrm{ng} / \mathrm{ml}$ of CMN1 (Fig. 2c). This phenomenon could be explained by disruption of apoptotic cells by factors present in partially purified CMN1.

\section{Discussion}

Our study unequivocally indicated that exposure to CMN1 and CMN2 resulted in induction of apoptosis in $\mathrm{HeLa}$ cells after $48 \mathrm{~h}$, but not in CHO cells. The activity depended on the concentration of the applied nuclease and the season of the year in which it was collected. Purified CMN2 collected in October showed lower proapoptotic activities in the same concentrations than CMN2 collected in May (Fig. 2a). The first reason could involve different post-translational modifications (PTMs) of such enzyme at the beginning of the vegetation period of the plant than at its end, in autumn. The second reason could be the presence of special cofactors, associated to protein molecules, different at the beginning than at the end of the vegetation period. CMN1 showed intermediary activity (Fig. 2a), but contained some other factors present in the purified fraction, so they could also be responsible for its activity. This is not surprising, because Chelidonium majus sap is also a rich source of many biologically active substances, such as alkaloids, flavonoids, phenolic acids and others. Seasonal changes in their composition related to the reproductive cycle of the plant were also observed [15].

$\mathrm{CMN} 1$ and $\mathrm{CMN} 2$ are $\mathrm{Ca}^{2+}$-dependent endonucleases and could be directly involved in induction or acceleration of apoptotic pathway in $\mathrm{HeLa}$ cells, derived from human cervical cancer. No apoptotic changes were seen after incubation of CMN1 and CMN2 in any concentration for 24 or $48 \mathrm{~h}$ with $\mathrm{CHO}$ cells, derived from Chinese hamster ovary. The data seem to indicate that, in contrast to $\mathrm{CHO}$ cells, HeLa cells were sensitive to the applied nucleases. For the moment, there is no satysfying explanation for this 
phenomenon. Possibly the fact, that HeLa cells are transformed with oncogenic human papillomavirus (HPV18), should be taken under consideration.

The ribonucleases from higher plants have been classically grouped into four main families of different substrate specificity (RNA or DNA), different $\mathrm{pH}$ optima and different susceptibility to EDTA [11]. Our results indicate that CMN1 of $20 \mathrm{kDa}$ might belong to $\mathrm{RN}$-ases class II, which comprise nucleases of $\mathrm{pH}$ optima between 6 and 7, molecular masses between 17 and $21 \mathrm{kDa}$, and low sensitivity to EDTA [11]. Possibly CMN1, also CMN2, nucleases could be engaged in PR-10 (pathogenesis-related protein class 10) activity $[16,17]$. At the moment, the mechanism of apoptotic cell death in HeLa cells remains difficult to be interpreted, but one should keep in mind the CMN potential for induction of proteins, responsible for apoptosis execution. It is certainly an important topic for future investigations; it seems that in certain conditions appropriate cells switch to an apoptotic cell death inducing endogenous mechanism, terminating in death without inflammation.

Acknowledgements: This work was financed by the Polish State Committee for Scientific Research (KBN) grant no. 2P05F 04127.

\section{References}

[1] Fik E, Dalgalarrondo M, Haertle T, Gozdzicka-Jozefiak A. Comparative biochemical analysis of lectin and nuclease from Chelidonium majus L. Acta Biochim Pol. 2000;47:413420.

[2] Nawrot R, Lesniewicz K, Pienkowska J, Gozdzicka-Jozefiak A. A novel extracellular peroxidase and nucleases from a milky sap of Chelidonium majus L. Fitoterapia. 2007;78:496501.

[3] Nawrot R, Kalinowski A, Gozdzicka-Jozefiak A. Proteomic analysis of Chelidonium majus milky sap using two-dimensional gel electrophoresis and tandem mass spectrometry. Phytochemistry. 2007;68:1612-1622.

[4] Sugiyama M, Ito J, Aoyagi S, Fukuda H. Endonucleases. Plant Mol Biol. 2000;44:387-397.
[ 5] Liu JJ, Ekramoddoullah KM. The family 10 of plant pathogenesis-related proteins: Their structure, regulation, and function in response to biotic and abiotic stresses. Physiol Mol Plant Pathol. 2006;68:3-13.

[6] Lowry OH, Rosebrough NJ, Farr AL, Randall RJ. Protein measurement with the Folin phenol reagent. J Biol Chem. 1951;193:265-275.

[7] Shevchenko A, Wilm M, Vorm O, Mann M. Mass spectrometric sequencing of proteins silver-stained polyacrylamide gels. Anal Chem. 1996;68:850-858.

[ 8] Heukeshoven J, Dernick R. Simplified method for silver staining of proteins in polyacrylamide gels and the mechanism of silver staining. Electrophoresis. 1985;6:103-112.

[ 9] Thelen MP, Northcote DH. Identification and purification of a nuclease from Zinnia elegans L.: a potential molecular marker for xylogenesis. Planta. 1989;179:181-195.

[10] Ito J, Fukuda H. ZEN1 is a key enzyme in the degradation of nuclear DNA during programmed cell death of tracheary elements. Plant Cell. 2002;14:3201-3211.

[11] Yen Y, Green PJ. Identification and properties of the major ribonucleases of Arabidopsis thaliana. Plant Physiol. 1991; 97:1487-1493.

[12] Bantignies B, Seguin J, Muzac I, Dedaldechamp F, Gulick P, Ibrahim R. Direct evidence for ribonucleolytic activity of a PR-10-like protein from white lupin roots. Plant Mol Biol. 2000;42:871-881.

[13] Fik E, Wolun-Cholewa M, Kistowska M, Warchol JB, Gozdzicka-Jozefiak A. Effect of lectin from Chelidonium majus L. on normal and cancer cells in culture. Folia Histochem Cytobiol. 2001;39:215-216.

[14] Hsia KC, Li CL, Yuan HS. Structural and functional insight into sugar-nonspecific nucleases in host defense. Curr Opin Struct Biol. 2005; 15:126-134.

[15] Tome F, Colombo ML. Distribution of alkaloids in Chelidonium majus and factors affecting their accumulation. Phytochemistry. 1995;40:37-39.

[16] Ekramoddoullah AKM. Physiology and molecular biology of a family of pathogenesis-related PR-10 proteins in conifers. $J$ Crop Improv. 2004;10:261-280.

[17] Park CJ, Kim KJ, Shin R, Park JM, Shin YC, Paek KH. Pathogenesis-related protein 10 isolated from hot pepper functions as a ribonuclease in an antiviral pathway. Plant $J$. 2004;37:186-198.

Submitted: 9 May, 2007 Accepted after reviews: 5 October, 2007 